\title{
ПОСТСОВЕТСКАЯ ИСТОРИОГРАФИЯ 1917 ГОДА И НЕКОТОРЫЕ ПРОБЛЕМЫ КОНТЕКСТУАЛИЗАЦИИ. СЛУЧАЙ АНТОНИО ГРАМШИ
}

\author{
НАТАЛЬЯ Г. ТЕРЕХОВА \\ Национальный исследовательский университет \\ «Высшая школа экономики» \\ Департамент иностранных языков, Кафедра иностранных языков \\ ул. Б. Ордынка, д. 47/7 с. 1, 115162, Москва, Россия \\ e-mail: nterekhova@hse.ru \\ (получено 6.08.2017; принято 10.09.2017)
}

\begin{abstract}
Post-Soviet Historiography of 1917 and certain problems of contextualization. Antonio Gramsci's Case

A quarter of a century ago, historians gained access to Soviet archives. Consequently, the events of the Revolution of 1917 finally received a comprehensive unbiased coverage by Russian scholars. The success of this work is impressive, but it also sets new tasks including the contextualization of the activities of foreign communists in Soviet Russia after the Bolsheviks came to power and established the Comintern. Among these figures was the famous and very popular Italian Antonio Gramsi.
\end{abstract}

\section{Key words}

Russian Revolution 1917, Post-Soviet Historiography, Comintern, "Philosophy Steamer" 1922, Show Trial under Lenin, Bolshevik's Persecution of Religion, Antonio Gramsci. 


\section{Резюме}

Четверть века назад историки получили доступ к советским архивам. Благодаря этому события Революции 1917 года наконец получили всестороннее непредвзятое освещение со стороны российских ученых. Успех этой работы впечатляет, но и ставит новые задачи, в том числе по осмыслению и контекстуализации деятельности иностранных коммунистов в Советской России после того, как большевики пришли к власти и учредили Коминтерн. К числу таких фигур принадлежит ставший знаменитым и весьма популярным итальянец Антонио Грамши.

\section{Ключевые слова}

Русская революция 1917 года, постсоветская историография, Коминтерн, «философский пароход», суд над эсерами в 1922 году, гонения большевиков на церковь, итальянский коммунист Антонио Грамши.

Нынешний год богат на юбилеи, среди которых нельзя не упомянуть 500 лет тезисам Мартина Лютера, 100 лет Октябрьской революции, 80 лет началу сталинских репрессий. Читатель, несомненно, добавит другие значимые события, по нашему мнению в этом же ряду стоит годовщина смерти Антонио Грамши, скончавшегося в апреле 1937 г. вскоре после освобождения из многолетнего заключения в фашистских застенках ${ }^{1}$. Интерес к идеям этого итальянского мыслителя, к его наследию растет во многих странах мира, особенно в Италии, в Бразилии, в Мексике, в США 2 , но мало затрагивает Россию, хотя связь его с этой страной - тема большая, полная неожиданных поворотов, насыщенная перспективной, актуальной проблематикой. Фигура этого политического деятеля неотделима от социалистической культуры первой четверти XX века, от распространения марксизма в Европе и в мире, от революционных событий 1917 года в России и их последствий для деятельности левых сил за пределами страны. Два аспекта, таким образом, необходимо учитывать при постановке проблемы, заявленной в заголовке - значительное, многократное расширение источниковой базы по событиям и процессам этогопериода, а также по главным

\footnotetext{
1 А. Грамши родился на о. Сардиния в 1891 г.

2 Работы на итальянском языке, посвященные А. Грамши, его идейному наследию выходят ежегодно и исчисляются десятками. См.: Eric J. Hobsbawm Gramsci in Europa e in America. Bari: Laterza, 1995. Среди недавних наибольший резонанс вызвали: M. Canali. Il tradimento. Gramsci, Togliatti e la verità negata. Venezia: Marsilio, 2013; G. Fabre. Lo scambio. Come Gramsci non fu liberato. Palermo: Sellerio Editore, 2015; N. Ghetti. La cartolina di Gramsci: A Mosca, tra politica e amo$r i$, 1922-1924. Roma: Donzelli Editore; Sagine, 2016. См. также на английском языке: A. Pearmain. Gramsci in Love. Winchester, Washington: Top Hat Books, 2015; P. Thomas. Gramsci and the Intellectuals: Modern Prince versus Passive Revolution. [B:] Marxism, Intellectuals, and Politics. Ed. by David Bates. London: Palgrave Macmillan, 2007; Perspectives on Gramsci: Politics, Culture and Social Theory. Ed. by J. Francese. New York, Routledge, 2009..
} 
действующим лицам этой исторической драмы, прежде всего, следует уделить внимание инициатору, организатору, теоретику и руководителю партии большевиков - В.И. Ленину.

Октябрьская революция стала для Грамши манящей целью, направлением, стимулом, идеологией, смыслом деятельности, отправной точкой развития, этому событию посвящены многие страницы его работ ${ }^{3}$. Знакомство ставшего туринским журналистом выходца из Сардинии с представителями партии большевиков произошло еще до событий судьбоносной осени 17-ого года. В промышленной столице Италии, где к тому времени были построены, став значительным фактором экономического развития, заводы ФИАТа, в левой прессе работал большевик, уроженец города Лодзь Арон Визнер. Именно он организовал в 1919 году встречу Антонио Грамши с «товарищем Деготем», бывшим одним из самых доверенных, близких В.И. Ленину эмиссаров только что организованного Третьего Интернационала, посланных в Европу с поручением поддержать единомышленников ${ }^{4}$. Спустя годы Владимир Деготь подробно рассказал о своих встречах с итальянскими социалистами в нескольких книгах воспоминаний, изданных в Советской России, современные российские исследователи также уделили внимание этой фигуре в своих работах 5 .

В течение последующих полутора лет Грамши популяризировал на страницах возглавляемой им туринской газеты «Ордине нуово» опыт большевиков, публиковал присланные из Москвы статьи и материалы. Вскоре ему довелось приехать в столицу первого в мире государства «диктатуры пролетариата». С мая 1922 г. по январь 1923 г. он жил в специально отведенной для иностранных коммунистов гостинице «Люкс» в центре города. Здесь же в Москве произошли важнейшие события его профессиональной жизни, что подтверждает, в частности, мемориальная доска на фасаде здания возле Кремля, где располагались кабинеты сотрудников различных комиссий Коминтерна ${ }^{6}$. Грамши состоял в нескольких из них, об этом рассказывают протоколы заседаний, изданные после того, как бывшие советские архивы стали доступны исследователям. Истории и деятельности этого учрежденного в начале 1919 году органа мировой революции, российские ученые за последние четверть века посвятили большое

3 A. D’Orsi. Gramsci. Una nuova biografia. Milano: Giangiacomo Feltrinelli, 2017; N. Terekhova N. L'Ottobre in Italia: Serrati, Bordiga, Gramsci. [B:] 1917 Ottobre Rosso. La Rivoluzione russa: i fatti, i protagonisti, il mito. A cura di A. Carioti. Milano: Corriere della sera, 2017.

4 Сайт "Russi in Italia" [Русские в Италии]. [Online:] <www.russinitalia.it>; S. Caprioglio. Un "compagno polacco" citato da Gramsci. «Rinascita», 13 марта 1965 г.; он же: Aron Wizner, un collaborator di Gramsci al "Grido del popolo". [B:] Mezzosecolo. Materiali di ricerca storica. Annali 1975, Torino: Guanda, 1976, c. 103-116; A. Venturi. L'emigrazione russa in Italia 1917-1921. Milano: Feltrinelli, 1979; Я. Леонтьев. Группа «русских большевиков» в Италии и эмиссары Коминтерна 1917-1922. [В:] Русские в Италии: культурное наследие эмиграции. Сост., науч. ред. М. Г. Талалая. Москва: Русский путь, 2006, с. 53-95.

5 М. Пантелеев. Агенты Коминтерна. Солдаты мировой революиии. Москва: Яуза; Эксмо, 2005.

6 Мемориальная доска А. Грамши размещена рядом с памятным знаком его венгерскому коллеге Бела Куну, расстрелянному в 1938 г. 
количество документальных исследований ${ }^{7}$, сконцентрировав внимание как на руководителях, так и на организационной структуре Третьего Интернационала, а также на его отдельных секциях по регионам - Латинская Америка, Африка, Средний и Ближний Восток, Балканы, и по странам - Германия, Финляндия, Испания, Китай, Вьетнам, Япония.

Во время своего пребывания в стране Советов Грамши довелось посетить также Петроград и знаменитый «город невест», русский центр текстильной промышленности Иваново-Вознесенск, где первая фабрика была организована в далеком 1742 г., а первая забастовка прошла в 1871 г. Спустя годы, в 1885 г. рабочим удалось камнями остановить казаков, присланных губернатором, и добиться повышения зарплат на 5 \%. В 1905 г. в Иваново-Вознесенске был избран первый Совет рабочих депутатов. Грамши же приезжал туда спустя 17 лет в связи с очень непростой политической ситуацией, после недавно подавленного выступления рабочих местных предприятий против нового режима. Во время этих поездок его сопровождала дочь близкого знакомого «вождя мирового пролетариата» Юлия Шухт. Девушка прекрасно владела итальянским языком, т.к. в юности жила с семьей в Италии и Швейцарии, помогала Антонио в качестве переводчика, а впоследствии стала матерью его детей. По причинам, изложенным в книге внука, полного тезки итальянского политика ${ }^{8}$, Юлия не поехала жить в Италию, и вскоре была навсегда разлучена со своим гражданским супругом. Эта разлука способствовала тому, что нить, связывавшая Грамши с Россией стала еще крепче, обретя помимо идеологической составляющей, романтическую, семейную, что нашло отражение в коллекции писем (частично опубликованных на русском языке Цецилией Кин во время краткого периода хрущевской «оттепели») .

Когда в ноябре 1926 года после вступления в силу закона Муссолини о запрете деятельности оппозиционных партий, избранный в 1924 году депутатом парламента Грамши был арестован, рядом с ним была, поддерживала его и помогала ему свояченица (сестра жены) Татьяна, ставшая ему верным и надежным другом, что подтверждает их обширная переписка9.

Внук Грамши подробно, в деталях восстановил перипетии жизни русско-итальянской семьи, в которой, по его словам, «царил матриархат». Автор рассказал о сложных межличностных, внутрисемейных отношениях с преобладающей, доминирующей ролью женщин, начало которым положила «стальная» рево-

\footnotetext{
7 А.Ю. Ватлин, Ф.И. Фирсов. Бухарин и Коминтерн. «Рабочий класс и социальный прогресс». Москва, 1990, с. 251-282; А.Ю. Ватлин. Троцкий и Коминтерн (1923-1933). Москва: Знание, 1991; А.Ю. Ватлин. Коминтерн: первые десять лет. Москва: Россия молодая, 1993; Г.М. Адибеков, Э.Н. Шахназарова, К.К. Шириня. Организационная структура Коминтерна. 1919-1943. Москва: РОССПЭН, 1997; История Коммунистического Интерначионала. Документальные очерки 1919-43. Под ред. А.О. Чубарьяна. Москва: Наука, 2002; Политбюро ЦК РКП б-ВКП (б) и Коминтерн 1919-43. Документы. Москва: РОССПЭН, 2004. [Online:] <http:// militera.lib.ru/docs/da/politburo_komintern/index.html> (12.08.2017).

8 A.Jr. Gramsci. La storia di una famiglia rivoluzionaria. Roma: Editori Riuniti, 2014.

9 А. Грамши. Письма из тюрьмы. Москва: Издательство по историческим наукам, 1957 (2016).
} 
люционерка Евгения, сестра двух вышеупомянутых женщин. С ней Антонио познакомился вскоре после приезда в Россию в санатории в Серебряном Бору, и, согласно недавнему исследованию, опубликованному в Италии, был влюблен и любим ${ }^{10}$. Евгения - особенная, но, в то же время, типичная для России конца XIX - начала XX вв. эмансипированная, увлеченная политикой девушка. Много было в тот период образованных, радикально настроенных женщин, активно занимавшихся революционной деятельностью.

Евгения работала под началом Надежды Крупской, супруги Ленина, которой после прихода большевиков к власти был доверен важный идеологический участок, - народное образование, борьба с неграмотностью и организация работы по воспитанию молодежи. Это всего лишь гипотеза, но представляется вероятным, что именно Евгения Шухт повлияла на изменение политической роли Антонио Грамши. Вполне очевиден момент, когда он, будучи одним из нескольких руководителей созданной в январе 1921 года при поддержке Интернационала Коммунистической партии Италии ${ }^{11}$, приобрел особую роль, став “il саро”, т.е. «начальником, руководителем». Это произошло после визита Грамши в Кремль, состоявшегося 25 октября 1922 года в 18.00 по приглашению лидера большевиков В.И. Ленина. Известно, что во время этой встречи два политика при помощи переводчика обсуждали проблемы итальянского Юга, усиление фашизма в Италии ${ }^{12}$, а также ситуацию в итальянской социалистической партии и возможность ее слияния с ИКП согласно замыслу руководителей Третьего Интернационала ${ }^{13}$. Беседа продолжалась два часа и имела значительные последствия для итальянского политического деятеля. К сожалению, сайт международного Общества изучения наследия Грамши International Gramsci Society в хронологической биографии не упоминает об этой встрече, в то время как аккуратно указан день, когда Грамши познакомился с Юлией Шухт.

Из Советской России Грамши отправился в Вену, где встречался с известной социалисткой Анжеликой Балабановой, стоявшей у истоков Коминтерна. Эволюция ее политических взглядов была стремительной, Балабанова спустя два года с трудом вырвалась из страны, управляемой большевиками, методы которых она не разделяла после подавления Кронштадского восстания ${ }^{14}$, когда были расстреляны моряки, требовавшие вернуть Советам власть, узурпированную партией. Из-за своей позиции относительно судьбы и роли лидера итальянских социалистов Джачинто Менотти Серрати бывшая сторонница Ленина при выезде из страны была предупреждена о том, что ей запрещено когда-ли-

10 M.L. Righi. Gramsci a Mosca tra amori e politica (1922-23). “Studi storici” 2011, № 4, c. 1015.

11 ИКП после Второй мировой войны стала самой крупной и весьма влиятельной в Западной Европе и в соцлагере партией.

12 Знаменитый марш на Рим, после которого Бенито Муссолини возглавил правительство, состоялся через несколько дней, в конце октября 1922 г.

13 Подробнее о деятельности ИСП см.: В.П. Любин. Социалисты в истории Италии. ИСП и ее наследники 1892-2006. Москва: Наука, 2007.

14 Кронштадтская трагедия 1921 года: документы (в 2-х тm.). Сост. И.И. Кудрявцев. Москва: РОССПЭН, 1999. 
бо «высказываться устно или письменно по итальянскому вопросу» ${ }^{15}$. Встреча с Балабановой была нужна Грамши для получения разрешения на пребывание в европейской стране, где у видной деятельницы международного социалистического движения были хорошие связи в правительственных кругах, при этом он скептически отзывался о ней в письмах к жене.

Крупнейшим экспертом по Грамши в России является Ирина Владимировна Григорьева. Первое ее выступление состоялось в далеком 1968 году на конференции советских и итальянских историков. Затем она участвовала во всех грамшианских встречах: в 1977 году во Флоренции, в 1987 году - в Москве, в 1997 году - в Кальяри, а десять лет спустя в круглом столе в Москве (2007 г.). Доклады, сделанные участниками десять лет назад, к сожалению, до сих пор не напечатаны. Тем не менее, И.В. Григорьева выступила тогда по ранее не затрагивавшейся исследователями проблематике: Грамши, проблема тоталитаризма и советская реальность 20-x и 30-х годов. С тех пор публичные мероприятия, посвященные ему, в России не проводились, тем не менее, думается, что тема, поднятая профессором Григорьевой в 2007 г., заслуживает внимания и дальнейшей разработки.

Находясь в Советской России без знания местного языка, будучи окруженным большевиками на заседаниях в Коминтерне, в гостинице «Люкс», в спецстоловой, в спецсанатории, в персональной машине с водителем и в семье, Грамши следовал в своей перцепции незнакомой страны и окружавшей его действительности исключительно линии партии, находившейся у власти. Известно, что иностранным работникам Коминтерна было запрещено вступать в контакт с местным населением, об этом свидетельствует сын одного из многолетних руководителей Третьего Интернационала Осипа Пятницкого, расстрелянного в 1938 г. $^{16}$. В письмах или заметках, написанных в заключении, не встречаются упоминания о том, что Грамши самому приходилось ездить в трамвае, нанимать извозчика, стоять в очереди за продуктами, разговаривать на улицах с солдатами, с крестьянами на рынке, общаться со студентами или рабочими кроме случаев специально организованных мероприятий, предполагавших его заранее подготовленные выступления с трибуны перед активом предприятий (в Иваново-Вознесенске). При этом необходимо учесть, что 27 октября 1917 года был введен тотальный запрет для небольшевистской печати, около четырехсот газет было закрыто сразу в течение двух недель, поэтому, даже если бы иностранец читал и понимал по-русски, он не смог бы воспользоваться альтернативными источниками информации. В связи с этим возникает вопрос: а было ли его восприятие новой русской действительности точным? Было ли оно объективным, поскольку сведения, которые до него доводились, были специальным образом отобраны, отцензурированы аппаратом Коминтерна, а в близком дружеском, семейном кругу обмен мнениями проходил под контролем «стальной» Евгении?

15 А. Балабанова. Моя жизнь - борьба. Мемуары русской социилистки 1897-1938. Москва: Центрполиграф, 2007.

16 В. Пятницкий. Осип Пятницкий и Коминтерн на весах истории. Минск: Харвест, 2004. 
Что было известно Грамши о реальных событиях, происходивших в то время в стране, в столице, в деревне?

После открытия бывших советских архивов в 1991 году, у исследователей, наконец, появилась возможность попытаться контекстуализировать пребывание Антонио Грамши в «советистской» (как он ее называл) России.

Период 1922-1923 годов был очень важным для новой власти, именно тогда был осуществлен разгром трех ключевых противников, к которым большевики причисляли Православную церковь, независимую интеллигенцию и политическую оппозицию. В феврале 1922 года В.И. Ленин подписал декрет, положивший начало процессу конфискации ценностей, принадлежавших церкви ${ }^{17}$ (речь не шла о золотых слитках или монетах, изымались предметы культа - оклады икон, кресты, серебряные цепочки и т.п.). Эти мероприятия обосновывались необходимостью сбора средств на борьбу с голодом, бушевавшим в стране, сопровождались репрессиями против служителей храмов и прихожан, разрушениями иконостасов, арестами и расстрелами.

Жаркие месяцы того же года (1922) оказались судьбоносными для интеллектуальной элиты страны, став необратимой катастрофой, известной в историографии как «философский пароход». Необходимо упомянуть детальные исследования российских историков, которые посвятили свои недавние работы этому трагическому сюжету ${ }^{18}$, а также изданный в 2010 году том Остракизм побольшевистски. Репрессии против политических оппонентов в 1921-1924 г2. ${ }^{19}$, насчитывающий более 800 страниц исторических документов. В течение двух месяцев была приведена в исполнение задуманная Лениным операция по принудительной эмиграции лучших представителей науки, медицины, юриспруденции. Видные философы, экономисты, профессора университетов, литераторы, историки, адвокаты были под конвоем погружены на пароходы и высланы

17 Н.Н. Покровский. Политбюро и Церковь. 1922-1923. «Новый мир» 1994, № 8; Я.Н. Щапов (ред.). Русская Православная иерковь и коммунистическое государство 1917-1941. Докуменmы и фотоматериаль. Москва Библейско-Богословского института, 1996; М. Данилушкин и др. История Русской Православной Церкви. Новый патриарший период. 1917-1970. Т. 1. Санкт-Петербург: Воскресение, 1997; Политбюро и церковь. Архивы Кремля. В 2-х кн. Москва - Новосибирск, 1997.

18 А.В. Квакин. Осмысление «философского парохода» 1922 года (к 80-летию административной высылки большевиками значительной группь видных российских интеллигентов. [В:] Толерантность и власть: судьбы российской интеллигениии. ред. М.Е. Главацкий. Пермь: Пермский региональный институт педагогических информационных технологий, 2002, с. 20-26; В.Г. Макаров, В.С. Христофоров (сост, авт. вст.ст.). Высылка вместо расстрела: Депортация интеллигеничи в документах ВЧК-ГПУ 1921-1923. Москва: Русский путь, 2005; «Очистим Россию надолго...» Репрессии против инакомыслящих. Конеи, 1921 - начало 1923 г.: Документьь. Москва: МФД Материк, 2008; В.Г. Макаров. Историко-философский анализ внутриполитической борьбы начала 1920-х годов и депортаиия инакомыслящих из Советской России. Москва: Русский путь, 2010.

19 Остракизм по-большевистски: Преследования политических оппонентов в 1921-1924 г2. Сост., предисл. В. Г. Макаров, В.С. Христофоров. Коммент. В.Г. Макаров. Москва: Русский путь. 
за рубежи своей Родины. Библиография на русском языке по этой теме обширна, сами высланные оставили бесценные свидетельства (мемуары известного итальяниста Михаила Осоргина были опубликованы в Париже в 1955 г., а на русском языке они увидели свет лишь в 1994г.). Работа другого вынужденного эмигранта крупного историка Сергея Мельгунова вышла в Германии в 1924 году, в СССР - в 1990г., а в Италии совсем недавно - в 2010 г.

После крушения СССР и последовавшего за ним открытия архивов значительные объемы источников и документов, рассказывающих о сложном периоде 1917-1924 годов, - о Гражданской войне, о значительной роли крестьянства в сопротивлении новой власти увидели свет в России ${ }^{20}$. Большой интерес вызвали работы по экономической истории этого периода, в которых, согласно авторам, Россия представляла собой более или менее здоровую жизнеспособную страну со значительным потенциалом, вполне способную к постепенному прогрессу, к эволюционному развитию общественных институтов, к устойчивому экономическому и социальному развитию. Мнение большинства современных российских историков значительно отличается от марксистской точки зрения, которой придерживался, в том числе и Грамши, о том, что экономика России в результате Первой мировой войны была полностью разрушена, находилась в упадке. ${ }^{21}$

Начавшаяся четверть века назад новая страница в истории России дает возможность ответить на вопрос: что изменилось с прекращением власти монопольной коммунистической идеологии в восприятии наследия Грамши? Его самое знаменитое сочинение, написанное в заключении, - Тюремные тетради, было переведено на русский язык в 1957 г., но не полностью, а только четверть всего объема. На русском языке увидели свет и другие его произведения, последнее из них - в 1991 г. Около двадцати переводчиков, среди которых сама Евгения Шухт, занимались в XX веке текстами Грамши.

Однако в XXI веке приходится констатировать слабый интерес читателей и издателей к этой фигуре. Фундаментальный библиографический труд «Италия кириллицей» приводит все изданные в России и СССР переводы с итальянского

20 В.П. Булдаков. Исторические метаморфозы «Красного Октября». [В:] Исторические исследования в России. Тендениии последних лет. Под ред. Г.А. Бордюгова. Москва: Аиро XXI, 1996; С.А. Павлюченков. Военный коммунизм в России. Власть и массы. Москва: РКТ, 1997; В.М. Бухараев, Д.И. Люкшин. Крестьяне России в 1917 году. Пиррова победа «общинной революиии». [В:] 1917 в судьбах России и мира. Москва: ИРИ РАН, 1998; В.В. Кондрашин. Крестьянское движение в Поволжье в 1918-1922 г2. Москва, 2001; Д.И. Люкшин. Вторая русская смута: крестьянское измерение. Москва: Аиро XXI, 2006; А.А. Куренышев. Крестьянские военно-политические организачии России. Повстанчество. 1918-1922. Москва: Компания Спутник Плюс, 2010; Гражданская война в России: энциклопедия катастрофы. Сост. и отв. ред.: Д.М. Володихин, научн. ред. С.В. Волков. Москва: Сибирский цирюльник, 2010.

21 А. Маркевич, М. Харрисон. Первая мировая война. Гражданская война и восстановление: национальный доход России в 1913-1928 г2. Москва: Мысль, 2013; Б.Н. Миронов. Российская империя: от традиции к модерну. Санкт-Петербург: Дмитрий Буланин, 2014; М.А. Давыдов. Двадиать лет до Великой войны. Российская модернизация Витте-Столыпина. СанктПетербург: Алетейя, 2016. 
языка на русский с 1913 г. в течение ста лет, по 2013 год. В разделе «Философия» имя Грамши встречается лишь однажды в связи с работой Записки по педагогике. Итальянские составители признают в предисловии: «в списке переведенных на русский язык книг по философии поражает значительное присутствие таких имен как Антонио Менегетти, Юлиус Эвола рядом с Джованни Джентиле и Чезаре Ломброзо. Для Италии это неоднозначные имена, но в Санкт-Петербурге Менегетти в 2004 г. учреждает кафедру онтопсихологии в Государственном университете, из работ Эволы в последние годы были переведены и опубликованы шесть книг. Имена Эволы и Менегетти подтверждают со всей очевидностью то, что перевод является чрезвычайно важным индикатором сложного взаимодействия двух культур, при котором получающая культура может следовать совершенно иным предпочтениям, чем те, что преобладают в исходной культуре» ${ }^{22}$.

Представляется оправданным более осторожное отношение к утверждениям о полном понимании и знании особенностей реальной русской действительности периода становления советской власти со стороны Грамши: его впечатления в период пребывания в стране акритичны, неотделимы от идеологизированной, мифологизированной картины, над созданием которой работала мощная машина советской пропаганды. После 1926 года, во время заключения доступ к информации был ограничен, хотя известно, что ему хоть и с перебоями, обусловленными цензурой задержками, все-таки доставлялась по запросу необходимая литература и периодика. Тем не менее, в итальянской историографии, философии и публицистике, во всем, что связано с особенностями становления и развития нового режима в России утверждения Грамши считаются весьма авторитетными, экспертными, несмотря на огромный пласт новых материалов, введенных в научный оборот и в общественный дискурс за минувшую четверть века. Остается признать справедливость слов, сказанных последним советским послом в Риме А.Л. Адамишиным в сентябре 2013 г. во время выступления на конференции в МГУ им. Ломоносова: «Италия и Россия должны больше изучать друг друга, честно говоря, мы мало друг друга знаем». И, думается, истоки такого взаимного восприятия следует искать на заре «короткого века». Некоторые историки этот феномен уже отметили, объяснив причины появления лакун и недостаточной информированности, отличавших итальянскую дипломатию и печать накануне и во время Октябрьской революции (Дж. Петракки) ${ }^{23}$. После событий поздней осени 1917 г. итальянское посольство возобновило работу в Москве лишь в 1924 году с признанием Советского Союза со стороны правительства Муссолини, когда, по словам Серджио Романо ${ }^{24}$, было дано начало «дружеским отношениям, связавшим обе страны между двумя [мировыми прим. авт.] войнами» ${ }^{25}$.

22 S. a cura di Pavan. Italia in Cirillico. Verona: Conoscere Eurasia Edizioni, 2013.

23 G. Petracchi. Da San Pietroburgo a Mosca: la diplomazia italiana in Russia, 1861-1941. Roma: Bonacci, 1993.

24 Посол Италии в СССР с 1985 по 1989 гг.

25 В своем обзоре истории двусторонних отношений С. Романо деликатно умолчал о 22 июня 1941 г., когда Муссолини вступил в войну на стороне Гитлера и осуществил оккупацию со- 
Политические круги Италии также отличала скудная осведомленность о происходивших в России событиях и процессах, историк Этторе Чиннелла недавно писал в связи с этим:

«Нельзя сказать, что итальянские социалисты накануне революции следили за политической жизнью в России. Не хватало информации о социалистическом движении, об особенностях, о внутренних дискуссиях (первоначально между эсерами и социал-демократами, а затем внутри русской социал-демократии). Прежде всего, была совершенно непонятна и казалась абсолютно неоправданной беспощадная полемика между большевиками и меньшевиками. Все социалисты в Европе и в Италии ненавидели тиранию царя и симпатизировали оппозиционным движениям».

Тем не менее, в знаменитый процесс против эсеров, членов крупнейшей с середины 90-х годов XIX в. партии в России, получившей большинство на выбоpax в разогнанное большевиками в январе 1918 года Учредительное собрание ${ }^{26}$, Грамши был вовлечен непосредственно. Власти привлекли к процессу многих находившихся тогда в Москве представителей иностранных компартий. Антонио была уготована роль защитника эсерки Лидии Коноплевой, неоднозначной фигуры, игравшей в процессе новейшим исследованиям провокационную роль. С окончанием советской власти появилась возможность познакомиться с документами, протоколами, заявлениями, с подробными стенограммами этого демонстративного мероприятия, получившего в современной историографии название «суд без суда» ${ }^{27}$. Теперь степень участия вовлеченных в него лиц изучена российскими историками в малейших подробностях ${ }^{28}$. Результаты их трудов опубликованы ведущим российском издательством «Росспэн».

Известно, что Грамши высоко ценил теоретические работы и практическую деятельность лидера большевиков В.И. Ленина, считал его максималистом и якобинцем, «деятельным, эффективным политиком, способным перевести марксизм из теории в практику, взять от этого учения все необходимое для преобразования мира» ${ }^{29}$. Итальянский коммунист оправдывал революционной целесообразностью чрезвычайные меры, предпринимаемые большевиками. Тем временем вождь мирового пролетариата давал следующие, опубликованные в советское время в полном собрании сочинений, указания:

«война не на жизнь, а на смерть богатым и прихлебателям, буржуазным интеллигентам...

с ними надо расправляться, при малейшем нарушении... В одном месте посадят в тюрьму... В другом - поставят их чистить сортиры. В третьем - снабдят их, по отбытии карце-

ветских территорий итальянскими войсками. См.: http://archiviostorico.corriere.it/2006/ febbraio/22/Italia_Urss_alti_bassi_tra_co_9_060222088.shtml

26 Л.Г. Протасов. Учредительное собрание: история рождения и гибели. Москва: РОССПЭН, 1987.

27 М. Янсен. Суд без суда, 1922 год: показательный процесс соииалистов-революиионеров. Москва: Возвращение, 1993.

28 К.Н. Морозов. Судебный процесс социалистов-революиионеров и тюремное противостояние 1922-1926: этика и тактика противоборства. Москва: РОССПЭН, 2005.

29 G. Liguori, P. Voza a cura di, Dizionario gramsciano. Roma: Carocci, 2009, c. 457. 
ра, желтыми билетами... В четвертом - расстреляют на месте... Чем разнообразнее, тем лучше, тем богаче будет общий опыт...» ${ }^{30}$

или перечисленные в телеграмме от 9 августа 1918 г.: «Пенза, Губисполком. ...провести беспощадный массовый террор против кулаков, попов и белогвардейцев; сомнительных запереть в концентрационный лагерь вне города». ${ }^{31}$

С крушением советского строя ведущим историкам и философам была предоставлена возможность первыми в составе специальной комиссии ознакомиться с рассекреченными документами архивного фонда основателя советского государства. И, как признавался один из членов специальной комиссии, увиденное и прочитанное вызвало у него, человека с солидной гуманитарной подготовкой, оторопь. Рассекреченные материалы представляли вождя мирового пролетариата не просто чрезвычайно жестоким человеком, но настоящим «человеконенавистником». Вот выдержки из некоторых из его телеграмм, засекреченных при советской власти:

«...Прекрасный план! Доканчивайте его вместе с Дзержинским. Под видом „зелёных“ (мы потом на них свалим) пройдём на 10-20 вёрст и перевешаем кулаков, попов, помещиков. Премия: 100.000 р. за повешенного...» ${ }^{32}$

«...Можете ли вы еще передать Теру, чтобы он всё приготовил для сожжения Баку полностью, в случае нашествия, и чтобы печатно объявил это в Баку». ${ }^{33}$

«Товарищам Кураеву, Бош, Минкину и другим пензенским коммунистам.

Товарищи! Восстание пяти волостей кулачья должно повести к беспощадному подавлению. Этого требует интерес всей революции, ибо теперь взят «последний решительный бой» с кулачьем. Образец надо дать. Повесить (непременно повесить, дабы народ видел) не меньше 100 заведомых кулаков, богатеев, кровопийц. Опубликовать их имена. Отнять у них весь хлеб. Назначить заложников - согласно вчерашней телеграмме. Сделать так, чтобы на сотни верст кругом народ видел, трепетал, знал, кричал: душат и задушат кровопийц кулаков. Телеграфируйте получение и исполнение. Ваш Ленин». ${ }^{34}$

В советской историографии было принято считать, что белый террор в стране начался летом 1918 года, а красный - после выхода постановления Совнаркома в сентябре того же года в качестве ответной меры. Современные российские историки придерживаются теперь иной точки зрения, они связывают

«начало красного террора с убийством царской семьи, с призывом Ленина к проведению террора в Петрограде в ответ на убийство Володарского, с резолюцией ВЦИК 29 июля 1918 г. о проведении массового террора против буржуазии, с тем, что террор составлял сущность советской системы, и до августа 1918 г. проводился фактически, а с 5 сентября 1918 г. - официально. ...Советские декреты либо фиксировали то, что уже происходило,

30 В.И. Ленин. Как нам организовать соревнование? Полное собрание сочинений. Т. 35. Москва: Политиздат, с. 200, 201, 204.

31 В.И. Ленин. Полное собрание сочинений. Т. 50. Москва: Политиздат, с. 143-144.

32 А.Л. Литвин. Красный и Белый террор в России в 1917-1922 годах. Москва: Эксмо, 2004.

33 Рукописное распоряжение В.И. Ленина председателю Бакинской Чрезвычайной Комиссии (ЧК) С. Тер-Габриэляну. Цит по кн.: Д.А. Волкогонов. Ленин. Политический портрет. В 2-х кн. Москва: АСТ, 1998.

34 А.Г. Латышев. Рассекреченный Ленин. Москва: МАРТ, 1996, с. 57. 
либо инициировали ускорение того, что, по мнению властей, замедляло свой ход. Среди причин, обусловивших победу большевизма в стране, были: нетерпимая к инакомыслию идеология, отвечающая сиюминутным чаяниям нищей массы, требующей социальной справедливости; право руководства распоряжаться кадрами, привилегиями, организацией властей, жестокий террор. Большевикам удалось создать иллюзорное представление о справедливой уравнительности, уверить большинство населения в том, что оно получит землю, хлеб, мир. Реалией стали война, голод, реквизиции и террор» ${ }^{35}$.

Российские историки подсчитали, что в стране за период 1917-1922 гг. погибло более 15 млн. человек, из них 1,3 млн. стали в 1918-1920 гг. жертвами массовых репрессий, бандитизма, погромов, пыток, расстрелов, участия в крестьянских выступлениях и их подавления ${ }^{36}$. По признанию одного современных российских исследователей «с тех пор, когда естественным течением вещей было отменено значение октябрьских событий семнадцатого года как нового пришествия, как главного рубежа в прошлой и грядущей истории человечества на пути к обществу свободы и справедливости, ... рассыпался тот краеугольный камень, на котором стояла отечественная историография» ${ }^{37}$.

Многие историки называют переворот в октябре 1917 г. леворадикальной революцией, отмечают его квазиглобальный характер, отмечают присущую ему ошибочность

«расчетов на цепную реакцию пролетарских революций по всему миру. Будучи в качестве последователей Маркса интенциональными, теоретическими глобалистами, большевики стали первой политической силой, которая стремилась руководствоваться глобальными идеями и схемами на практике. Абсолютные цели требовали доктринальной абсолютизации... Классовые интересы чаще всего понимались как решающая детерминанта человеческого поведения, их сцепляющая функция переоценивалась, а внутриклассовые различия, как и межклассовые компромиссы недооценивались» ${ }^{38}$.

Большевики преувеличивали степень радикализации масс не только в Европе, но и в самой России. Тем не менее, по мнению российских исследователей в тот момент «векторы деструктивной активности большевиков и радикализированных масс совпали, но они самым негативным образом проявились в последующие годы, когда формировалось новое общество».

В виду низкого уровня «революционного» сознания большинства населения революционерам, движимым «непродуктивной бескомпромиссностью», «ошалелостью буревестника» («пусть сильнее грянет буря»; «чем хуже - тем лучше»), приходилось прибегать к репрессивным методам и командно-мобилизационным практикам. Уже в годы Гражданской войны объектами репрессий стали представители не только привилегированных («эксплуататорских») классов,

\footnotetext{
35 А.Л. Литвин. Красный и Белый террор в России...

36 А.Л. Литвин. Красный и Белый террор в России...

37 С.А. Павлюченков. Военный коммунизм - в плену большевистской доктрины. [В:] Исторические исследования в России. Тенденции последних лет. Г.А. Под ред. Бордюгова. Москва: Аиро XXI, 2013, с. 222-238.

38 Ю.И. Игрицкий. Революиии 1917 года: уроки для радикалов, либералов и консерваторов. «Вопросы истории», 2008, № 5.
} 
но крестьяне и сами рабочие, от имени которых действовали большевики (расстрелы в Астрахани, Царицыне, на Урале...).

В феврале 1917 г. партия ВКП (б) насчитывала 24 тысячи членов, ликовавших по случаю падения самодержавия, и в те месяцы они были не более радикальны, чем меньшевики и эсеры, все они были настроены работать в режиме двоевластия.

По мнению историка Ю.И. Игрицкого «своими Апрельскими тезисами резко сдвинул партию влево. Как вспоминал Ф. Раскольников, встречавший возвращавшегося из эмиграции Ленина на подъезде к Петрограду, его речь на площади Финляндского вокзала с призывом к борьбе против Временного правительства «произвела целую революцию в сознании партии». Непримиримость Ленина и Троцкого не позволила достичь межпартийного политического компромисса на Демократическом совещании в сентябре 1917 г., сорвав возможность формирования даже однородного социалистического правительства,...что стало решающим в судьбах российской демократии»... Осенью 250-300 тыс. членов большевистской партии отличал «куда более боевой, неуступчивый и властолюбивый» подход, приведший к длительной и кровопролитной гражданской войне, «губительно повлиявшей на дальнейший ход российской истории» ${ }^{39}$.

Под углом зрения получившей в настоящее время широкое распространение социальной психологии и антропологии рассматривает этот период признанный ведущим специалистом по проблемам Великой русской революции историк В.П. Булдаков. По его мнению, марксизм, в качестве квазирелигии, соответствовал «структуре перевозбужденного синкретического сознания» населения. Он считает, что «в 1917 г. произошел спонтанный вброс примордиалистских представлений в псевдоклассовую среду» ${ }^{40}$. Представляется, однако, что упомянутый «вброс» не был таким уж спонтанным. Агитация большевиков среди солдатской массы, состоявшей из крестьян, торопившихся оставить фронт и успеть домой к дележу земли, была чрезвычайно энергичной, а пропаганда - весьма талантливой.

Таким образом, ни о какой апологии октябрьских событий и последовавших за ними массового террора и гражданской войны в рамках широкого общественного дискурса говорить не приходится, при этом в зону отторжения и критического восприятия попадают и зарубежные последователи идейного вдохновителя большевистской революции и последовавшей за ней «трагедии огромной страны». По всей видимости, незнание источников, обусловленное нерешенностью проблемы перевода с русского языка, по-прежнему влияет на устойчивость парадигмы, созданной советской коммунистической историографией и пропагандой в тот период, когда финансирование работы переводчиков осуществлялось на постоянной и регулярной основе идеологическим отделом

\footnotetext{
39 Ю.И. Игрицкий. Революиии 1917 года..., с. 119.

40 В.П. Булдаков. Quo vadis? Кризисы в России: пути преодоления. Москва: РОССПЭН, 2007, с. 89. См. также другие работы автора: Красная смута. Природа и последствия революиионного насилия. Москва: РОССПЭН, 2010; Хаос и этнос. Этнические конбликты в России 1917-18 г2. Условия возникновения и последствия, хроника, комментарии, анализ. Москва: Новый хронограф, 2010.
} 
ВКП (б), а затем КПСС. Остается надеяться, что со временем работы и публикации российских историков найдут своих читателей за рубежом, и тогда, вероятно, появится новый, более плодотворный ракурс исследований, посвященных фигуре и наследию Антонио Грамши в стране, с которой он был так тесно связан.

\section{Литература}

Адибеков Г.М., Шахназарова Э.Н., Шириня К.К. Организационная структура Коминтерна. 1919-1943. Москва: РОССПЭН, 1997.

Балабанова А. Моя жизнь - борьба. Мемуары русской социалистки 1897-1938. Москва, Центрполиграф, 2007.

Булдаков В.П. Qио vadis? Кризисы в России: пути преодоления. Москва: РОССПЭН, 2007.

Булдаков В.П. Красная смута. Природа и последствия революиионного насилия. Москва: РОССПЭН, 1997, 2010.

Булдаков В.П. Хаос и этнос. Этнические конфликты в России 1917-18 гг. Условия возникновения и последствия, хроника, комментарии, анализ. Москва: Новый хронограф, 2011.

Булдаков В.П. Исторические метаморфозы «КрасногоОктября». [В:] Исторические исследования в России. Тенденции последних лет. Под ред. Г.А. Бордюгова. Москва: Аиро XXI, 2013.

Бухараев В.М., Люкшин Д.И. Крестьяне России в 1917 году. Пиррова победа «общинной революиии». [В:] 1917 в судьбах России и мира. Февральская революиия: от новых источников $\kappa$ новому осмыслению. РАН, Государственный архив РФ. Москва: ИРИ РАН, 1998.

Ватлин А.Ю. Троикий и Коминтерн (1923-1933). Москва: Знание, 1991.

Ватлин А.Ю. Коминтерн: первые десять лет. Москва: Россия молодая, 1993.

Ватлин А.Ю. Коминтерн: Идеи, решения, судьбы. Москва, РОССПЭН, 2009.

Ватлин А.Ю., Фирсов Ф.И. Бухарин и Коминтерн. «Рабочий класс и социальный прогресс». Москва, 1990, с. 251-282.

Волкогонов Д.А. Ленин. Политический портрет. В 2-х кн. Москва: АСТ, 1998.

Гражданская война в России: энциклопедия катастрофбы. Сост. и отв. ред.: Д.М. Володихин, научн. ред. Волков С.В. Москва, 2010.

Гражданская война в России: энииклопедия катастрофы. Сост. и отв. ред.: Д.М. Володихин, научн. ред. С.В. Волков. Москва: Сибирский цирюльник, 2010.

Грамши А. Письма из тюрьмы. Москва: Издательство по историческим наукам, 1957.

Давыдов М.А. Двадизать лет до Великой войны. Российская модернизация Витте-Стольпина. Санкт-Петербург: Алетейя, 2016.

Данилушкин М. и др. История Русской Православной Церкви. Новый патриариий период. 1917-1970. Т. 1. Санкт-Петербург: Воскресение, 1997.

Игрицкий Ю.И. Революиии 1917 года: уроки для радикалов, либералов и консерваторов. «Вопросы истории», 2008, № 5.

История Коммунистического Интернационала. Документальные очерки 1919-43. Под ред. А.О. Чубарьяна. Москва: Наука, 2002.

Квакин А.В. Осмысление «философского парохода» 1922 года (к 80-летию административной высылки большевиками значительной группы видных российских интеллигентов). [В:] Толерантность и власть: судьбы российской интеллигениии. ред. М.Е. Главацкий. Пермь: Пермский региональный институт педагогических информационных технологий, 2002 , c. $20-26$. 
Кондрашин В.В. Крестьянское движение в Поволжье в 1918-1922 г2. Москва: Янус-К, 2001.

Кронштадтская трагедия 1921 года: документы (в 2-х тm.). Сост. И. И. Кудрявцев. Москва, РОССПЭН, 1999.

Куренышев А.А. Крестьянские военно-политические организации России. Повстанчество. 1918-1922. Москва: Компания Спутник Плюс, 2010.

Латышев А.Г. Рассекреченный Ленин. Москва: МАРТ, 1996.

Ленин В.И. Как нам организовать соревнование? Полное собрание сочинений. Т. 35. Москва: Политиздат, 1974.

Ленин В.И. Полное собрание сочинений. Т. 50. Москва: Политиздат, 1970.

Леонтьев Я.В. Группа «русских большевиков» в Италии и эмиссары Коминтерна 1917-1922. [В:] Русские в Италии: культурное наследие эмиграции. Сост., науч. ред. М.Г. Талалая. Москва, Русский путь, 2006, с. 53-95.

Литвин А.Л. Красныцй и Белый террор в России в 1917-1922 годах. Москва: Эксмо, 2004.

Любин В.П. Социалисты в истории Италии. ИСП и ее наследники 1892-2006. Москва, Наука, 2007.

Люкшин Д.И. Вторая русская смута: крестьянское измерение. Москва: Аиро XXI, 2006.

Макаров В.Г., Христофоров В.С. (сост.). Высылка вместо расстрела: Депортация интеллигеници в документах ВЧК-ГПУ 1921-1923. Москва: Русский путь, 2005.

Макаров В.Г. Историко-философский анализ внутриполитической борьбы начала 1920-х годов и депортация инакомыстящих из Советской России. Москва: Русский путь, 2010.

Маркевич А., Харрисон М. Первая мировая война. Гражданская война и восстановление: наизиональный доход России в 1913-1928 гz. Москва: Мысль, 2013.

Миронов Б.Н. Российская империя: от традищии к модерну. Санкт-Петербург: Дмитрий Буланин, 2014.

Морозов К.Н. Судебный процесс социалистов-революичонеров и тюремное противостояние 1922-1926: этика и тактика противоборства. Москва: РОССПЭН, 2005.

Остракизм по-большевистски: преследования политических оппонентов в 1921-1924 г2. Сост., предисл. В.Г. Макаров, В.С. Христофоров. Коммент. В.Г. Макаров. Москва: Русский путь.

«Очистим Россию надолго...» Репрессии против инакомыслящих. Конеи, 1921 - начало 1923 г.: Документы. Москва: МФД Материк, 2008.

Павлюченков С.А. Военный коммунизм в России. Власть и массы. Москва: РКТ,1997.

Павлюченков С.А. Военный коммунизм - в плену большевистской доктрины. [В:] Исторические исследования в России. Тенденциии последних лет. Г.А. Под ред. Бордюгова. Москва: Аиро XXI, 2013, с. 222-238.

Пантелеев М. Агенты Коминтерна. Солдаты мировой революиии. Москва, Яуза; Эксмо, 2005. Покровский Н.Н. Политбюро и Церковъ. 1922-1923. «Новый мир» 1994, № 8.

Политбюро и церковь. Архивы Кремля. В 2-х кн. Москва - Новосибирск: РОССПЭН, Сибирский хронограф, 1997.

Политбюро ЦК РКП б-ВКП (б) и Коминтерн 1919-43. Документы. Москва: РОССПЭН, 2004. Протасов Л.Г. Уиредительное собрание: история рождения и гибели. Москва, РОССПЭН, 1997. Пятницкий В. Осип Пятницкий и Коминтерн на весах истории. Минск: Харвест, 2004.

Щапов Я.Н. (ред.). Русская Православная иерковь и коммунистическое государство 19171941. Документы и фотоматериалы. Москва: Издательство Библейско-Богословского института, 1996.

Янсен М. Суд без суда, 1922 год: показательный процесс соииалистов-революиионеров. Москва: Возвращение, 1993.

Canali M. Il tradimento. Gramsci, Togliatti e la verità negata, Venezia: Marsilio, 2013.

Caprioglio S. Un "compagno polacco" citato da Gramsci. "Rinascita”, 13 marzo 1965. 
Caprioglio S. Aron Wizner, un collaborator di Gramsci al "Grido del popolo". [B:] Mezzosecolo. Materiali di ricerca storica. Annali 1975. Torino: Guanda, 1976, c. 103-116.

D’Orsi A. Gramsci. Una nuova biografia. Milano: Feltrinelli, 2017.

Fabre G. Lo scambio. Come Gramsci non fu liberato. Palermo: Sellerio Editore, 2015.

Ghetti N. La cartolina di Gramsci: A Mosca, tra politica e amori, 1922-1924. Roma: Donzelli Editore, 2016.

Gramsci A.Jr. La storia di una famiglia rivoluzionaria. Roma: Editori Riuniti, 2014.

Hobsbawm E.J., Gramsci in Europa e in America, Bari: Laterza, 1995.

Liguori G., Voza P. a cura di. Dizionario gramsciano. Roma: Carocci, 2009.

Pavan S. a cura di. Italia in Cirillico. Verona: Conoscere Eurasia Edizioni, 2013.

Pearmain A. Gramsci in Love. Winchester, Washington: Top Hat Books, 2015.

Perspectives on Gramsci: Politics, Culture and Social Theory. Ed. by J. Francese. New York, Routledge, 2009.

Petracchi G. Da San Pietroburgo a Mosca: la diplomazia italiana in Russia, 1861-1941. Roma: Bonacci, 1993.

Righi M.L. Gramsci a Mosca tra amori e politica (1922-23). “Studi storici” 2011, № 4, c. 1015.

"Russi in Italia” [Русские в Италии]. [Online:] <www.russinitalia.it> (12.08.2017).

Terekhova N. L'Ottobre in Italia: Serrati, Bordiga, Gramsci. [B:] 1917 Ottobre Rosso. La Rivoluzione russa: i fatti, i protagonisti, il mito. A cura di A. Carioti. Milano: Corriere della sera, 2017.

Thomas P. Gramsci and the Intellectuals: Modern Prince versus Passive Revolution. [B:] Marxism, Intellectuals, and Politics. Ed. by David Bates. London: Palgrave Macmillan, 2007.

Venturi A. L'emigrazione russa in Italia 1917-1921. Milano: Feltrinelli, 1979. 